\title{
Serum Levels of Ferritin, Copper, and Zinc in Patients with Oral Cancer
}

\author{
Maryam Baharvand ${ }^{1}$, Soheila Manifar ${ }^{2}$, Reihaneh Akkafan ${ }^{3}$, Hamed Mortazavi $^{1}$, Siamak Sabour ${ }^{4}$
}

Background: Apart from the crucial role of micronutrients like copper, iron, and zinc in the functions of body enzymes, it seems that changes in the serum levels of these biomarkers may play a role in the pathogenesis of oral cancer. The aim of this study was to measure the serum levels of ferritin, copper, and zinc in patients with oral malignancies.

Methods: $\quad$ Sixty consecutive patients with oral cancer, together with 66 age- and sex-matched controls were enrolled in this cross-sectional study. The serum levels of ferritin, copper, and zinc were measured in both patients and healthy individuals. Data were statistically analyzed by Student's $t$-test and Mann-Whitney U test.

Results: In patients with oral cancer, the serum levels of ferritin, copper, and zinc were $267.41 \pm 249.45,209.85 \pm 160.28$, and $113.51 \pm 52.30 \mathrm{mg} / \mathrm{dl}$, respectively. In the control group, the serum levels of ferritin, copper, and zinc were reported to be $106.13 \pm 72.96,114.20 \pm 38.69$,

\section{At a Glance Commentary Scientific background of the subject}

Alteration in micronutrients seems to play a role in the pathogenesis of some malignant lesions, presumably due to their role in functions of body enzymes.

\section{What this study adds to the field}

According to our results, serum levels of ferritin, copper, and zinc in patients with oral cancer were significantly higher than those of healthy people. Therefore alterations in micronutrients should be addressed in future studies regarding prevention, diagnosis, treatment, and prognosis of cancerous lesions. and $64.57 \pm 31.54 \mathrm{mg} / \mathrm{dl}$, respectively. The mean serum values of ferritin, copper, and zinc in cancerous patients were significantly higher than in controls $(p<0.001)$.

Conclusions: The serum levels of ferritin, copper, and zinc in oral cancer patients were significantly higher than in control group subjects.

(Biomed J 2014;37:331-336)

Key words: copper, ferritin, oral cancer, zinc

$\mathrm{O}$ ral cancer is the sixth most common cancer in the world. ${ }^{[1]}$ Prevalence of oral cancer in countries such as India, Brazil, and parts of France stands higher than the global standard. Although great advances have been made in cancer treatment modalities, its 5-year survival has not changed dramatically. The known etiologic factors of oral cancer are consumption of alcohol or tobacco, and infection by some kinds of viruses, heredity, Candida, and diet. The most commonly affected areas by oral cancer are the tongue, buccal mucosa, gingivae, and lips, and the least common area to be involved is the palate. It should be further added that among individuals with reverse smoking habit (putting the fired extreme of the cigarette inside the mouth with the cigarette being held by the teeth and lips, the seal provided by the lips allows slow inhaling of the cigarette smoke), the most common area affected by oral cancer is the palate. ${ }^{[2,3]}$

Some nutrients like Iron, zinc, copper, and calcium seem to play a role in the pathologic processes of the human body, presumably due to their role in making body enzymes. Some studies have reported that huge amounts of arsenic

From the ${ }^{1}$ Department of Oral Medicine, Dental School, Shahid Beheshti University of Medical Sciences, Tehran, Iran; ${ }^{2}$ Department of Oral Medicine, Imam Khomeini Hospital, Tehran University of Medical Sciences, Tehran, Iran; ${ }^{3}$ General Dental Practitioner, Dental School, Shahid Beheshti University of Medical Sciences, Tehran, Iran; ${ }^{4}$ Department of Clinical Epidemiology, Dental School, Shahid Beheshti University of Medical Sciences, Tehran, Iran

Received: Apr. 30, 2013; Accepted: Nov. 19, 2013

Correspondence to: Dr. Hamed Mortazavi, Department of Oral Medicine, Dental School, Shahid Beheshti University of Medical Sciences, Iran. Daneshjoo Blvd, Chamran Highway, Tehran, Iran. Tel: 98-2129902311; E-mail: mortazavi57@ yahoo.com

DOI: $10.4103 / 2319-4170.132888$ 
were found in skin and bladder cancer, cadmium in breast and prostate cancers, and copper and iron in respiratory and urinary tract cancers. ${ }^{[4]}$ Undoubtedly, by early diagnosis of precancerous lesions based on the values of micronutrients, the occurrence of cancers may be decreased..$^{[5,6]}$ Moreover, shortage of zinc has been reported in a few malignant lesions, which may interfere with the healing of lesions, functional defect of the immune system, and causes acceleration of tumor growth among animals..$^{[7-9]}$ Due to the crucial role of copper, ferritin, and selenium in the structures of various body enzymes, it seems that changes in their serum levels play a role in the pathogenesis of oral cancer.

Iron (stored in the form of ferritin) is one of the main micronutrients whose insufficiency that is prevalent all over the world may cause oral cancer by inducing oxidative stress. Lack of balance between oxidative events and ability to remove them by enzymatic and non-enzymatic antioxidants results in oxidative stress. This reaction causes serious damage to cells and DNA because of producing excessive free radicals or decreasing the antioxidant defense or both. ${ }^{[10,11]}$ Oxidative damages are mostly followed by decline in the function of antioxidant enzymes. Decrease or increase of rare elements such as zinc, copper, and ferritin may influence the activities of antioxidant enzymes as well. ${ }^{[12,13]}$ Meanwhile, some remarkable statistical changes in the distribution of nutritional elements such as iron and copper in patients with various neoplasms have been reported. ${ }^{[14]}$

Consequently, serum level of micronutrients has been propounded as an effective biochemical marker in the diagnosis of oral cancer whose significance has recently been put forth by researchers and has opened a new way for diagnosis and treatment of many diseases, especially blood dyscrasias, accordingly. In recent years, micronutrients have been examined to a great extent in order to evaluate their probable role in the etiology of various kinds of cancers. Measurement of serum levels of micronutrients is not only useful for diagnosis but also an appropriate guide for prognosis of the disease. ${ }^{[15]}$

This research has been conducted to measure the quantities of copper, ferritin, and zinc in blood of patients with oral cancer.

\section{METHODS}

This cross-sectional study was conducted on 60 patients with oral and maxillofacial cancer at the Cancer Institute of Tehran University of Medical Sciences and 66 otherwise healthy persons. Subjects of the control group neither had cancer nor suffered from systemic diseases. Meanwhile, they were matched with cancer patients in terms of age and gender. The control group and cancer group patients had not used food supplements either.

At first, respective examinations were conducted on the inpatients hospitalized at the Cancer Institute after the required authorizations were obtained. Then, a data form including demographics, and characteristics of lesions, as well as informed written consent were completed for them. At the hospital, $5 \mathrm{ml}$ of blood sample of the patients was collected by registered nurses and then transferred to acid-wash tubes. Finally, the samples were transferred to the laboratory of the hospital. Then, the blood samples were centrifuged, the serum part was separated and kept in a refrigerator at $70^{\circ} \mathrm{C}$. Finally, all samples were analyzed at once for minimizing error. In order to measure the quantity of ferritin in serum, immunoenzymatic kits of Padtan-Elm Company (Tehran, Iran) were used. Quantities of zinc and copper were measured using the kits of Grainer Company (Frickenhausen, Germany).

Measurement of zinc was done by means of colorimetric test with 5-Brom-PAPS (2-(5-Bromo-2-pyridiylazo)5 -[N-n-propyl-N- (3-sulfopropyl) amino] phenol) and that of copper was conducted using colorimetric test with dibrom-PAESA (4-(3,5-Dibromo-2-pyridylazo)-N-ethyl-N-sulfopropylaniline) method by an autoanalyzer (Mindray BS-380, Shenzhen, China). Moreover, ferritin was measured by means of an ELISA (enzyme-linked immunosorbent assay) Reader (Alpha Diagnostic Intl. Inc., I San Antonio, Texas, USA).

Mean and standard deviation of the quantitative values of micronutrients in patients and healthy people were determined, and the frequency (percentage) of different kinds of oral cancerous lesions with location of tumors in patients was estimated accordingly. Quantities of ferritin, copper, and zinc in the two groups of patients and control were compared using Mann-Whitney U non-parametric test because the distribution of these variables was not normal. The same variables were distributed normally when compared between different sexes in case and control groups. Therefore, Student's $t$-test was used for statistical analysis. Distribution of gender in cancerous and non-cancerous patients was analyzed using Chi-square test. SPSS software version 18 was used for statistical analysis.

\section{RESULTS}

This research was conducted on 60 patients with oral cancer and 66 healthy persons. Average age of patients with oral cancer was $61.43 \pm 15.73$ years and that of the control group subjects was $59.8 \pm 13.65$ years. Student's $t$-test showed that there was no significant difference between the two groups with regard to age $(p=0.533)$. Of the $60 \mathrm{pa-}$ tients with oral cancer, 35 (26.9\% of total) were men and 25 (19.2\% of total) were women. Among the individuals of the control group $(n=66), 40$ persons ( $30.8 \%$ of total) were men and 26 (20\% of total) were women. Chi-square test showed that there was no significant difference between the two groups in terms of $\operatorname{sex}(p=0.891)$. 
The most frequent kind of cancer among our patients was squamous cell carcinoma (SCC). No significant difference was found between men and women in terms of tumor type $(p=0.452)$.

Mean of ferritin level in the cancer group $(267.41 \pm 249.45 \mathrm{mg} / \mathrm{dl})$ was significantly higher than in the control group $(106.13 \pm 72.96 \mathrm{mg} / \mathrm{dl})(p<0.001)$ [Table 1]. Meanwhile, the values of ferritin in men and women with cancer were higher than the values in their healthy counterparts [Table 2]. Furthermore, the average of ferritin in cancerous men was significantly higher than in cancerous women $(p=0.020)$.

The average of copper in the serum of patients with oral cancer $(209.85 \pm 160.28 \mathrm{mg} / \mathrm{dl})$ was significantly higher than in the control group $(114.20 \pm 38.69 \mathrm{mg} / \mathrm{dl})(p<0.001)$. Although not significant, the serum level of copper in men and women suffering from cancer was higher than the level in men and women of the control group [Table 2].

The average of serum zinc level in patients with oral cancer $(113.51 \pm 52.30 \mathrm{mg} / \mathrm{dl})$ was significantly higher than in the control group $(64.57 \pm 31.54 \mathrm{mg} / \mathrm{dl})(p<0.001)$ [Table 1]. Moreover, the serum level of zinc in cancerous men was higher than that of women, but without a significant difference [Table 2].

Values of serum ferritin, zinc, and copper based on cancer location have been given in Table 3 .

Patients having cancer in their tongue had the highest value of serum ferritin, and those with cancer in the floor of the mouth showed the least value of serum ferritin. The highest values of copper and zinc in cancerous patients were observed in lower lip and retromolar trigone, respectively, whereas the least values were seen in alveolar ridge and buccal mucosa.

\section{DISCUSSION}

Results showed that the serum copper level in patients with oral cancers compared to the individuals of healthy group showed a significant increase. The above findings are inconsistent with the results obtained in bladder, ${ }^{[16]}$ breast, ${ }^{[17]}$ colorectal, ${ }^{[18]}$ and gastrointestinal cancers. ${ }^{[18,19]}$ In another study, the serum levels of copper in cancerous and precancerous lesions were found to be significantly increased. ${ }^{[15]}$

Meanwhile, it has been found that $\mathrm{Cu}$ chelator compounds may act as tumor restraining factors. ${ }^{[20]}$ According to a research conducted in this regard, Tetrathiomolybdate (TTM) has been found as a copper chelator in different kinds of cancers, which is capable of stopping tumor growth and preventing recurrence. ${ }^{[21]}$ Copper ion plays a prominent role in producing free oxygen metabolites due to oxidation and regeneration activity. ${ }^{[22]}$ Free radicals are able to connect to natural parts of cell, leading to peroxidation of lipids, oxidation of proteins, and destruction of nucleic acids. ${ }^{[17]}$
Table 1: Serum levels of ferritin, copper, and zinc in case and control groups

\begin{tabular}{lccc}
\hline & $\begin{array}{c}\text { Ferritin } \\
(\mathrm{mg} / \mathrm{dl})\end{array}$ & $\begin{array}{c}\text { Copper }^{\mathrm{b}} \\
(\mathrm{mg} / \mathrm{dl})\end{array}$ & $\begin{array}{c}\text { Zinc }^{\mathrm{c}} \\
(\mathrm{mg} / \mathrm{dl})\end{array}$ \\
\hline $\begin{array}{l}\text { Cancerous } \\
\text { patients }(n=60)\end{array}$ & & & \\
$\quad$ Mean & $267.41 \pm 249.45$ & $209.85 \pm 160.28$ & $113.51 \pm 52.30$ \\
Mode & 203.50 & 167.51 & 103.50 \\
Control group & & & \\
$(n=66)$ & & & \\
Mean & $106.13 \pm 72.96$ & $114.20 \pm 38.69$ & $64.57 \pm 31.54$ \\
Mode & 89.51 & 112 & 61.52 \\
$p$ value & $<0.001$ & $<0.001$ & $<0.001$ \\
\hline
\end{tabular}

${ }^{\mathrm{a} N o r m a l}$ value: Men; 20-250; women; $10-120 .{ }^{\mathrm{b} N o r m a l ~ v a l u e: ~ M e n ; ~}$ 70-145; women; 80-155. 'Normal value: Men; 72.6-127; women; 70-114

Table 2: Serum levels of ferritin, copper, and zinc in case and control groups according to their sex

\begin{tabular}{lccc}
\hline & $\begin{array}{c}\text { Ferritin } \\
(\mathrm{mean} \pm \mathrm{SD}), \\
\mathrm{mg} / \mathrm{dl}\end{array}$ & $\begin{array}{c}\text { Copper } \\
(\mathrm{mean} \pm \mathrm{SD}), \\
\mathrm{mg} / \mathrm{dl}\end{array}$ & $\begin{array}{c}\text { Zinc } \\
(\mathrm{mean} \pm \mathrm{SD}), \\
\mathrm{mg} / \mathrm{dl}\end{array}$ \\
\hline $\begin{array}{l}\text { Cancerous } \\
\text { patients }(n)\end{array}$ & & & \\
$\quad$ Male $(35)$ & $322.70 \pm 294.41$ & $227.70 \pm 200.40$ & $119.62 \pm 64.10$ \\
Female $(25)$ & $189.90 \pm 145.20$ & $184.71 \pm 71.43$ & $104.91 \pm 27.50$ \\
$p$ value & 0.020 & 0.243 & 0.232 \\
Control & & & \\
group $(n)$ & & & \\
Male $(40)$ & $123.41 \pm 75.50$ & $109 \pm 31.10$ & $67.92 \pm 31.71$ \\
Female $(26)$ & $79.60 \pm 61.10$ & $122.13 \pm 47.60$ & $59.4 \pm 31.11$ \\
$p$ value & $<0.001$ & $<0.001$ & $<0.001$ \\
\hline
\end{tabular}

Table 3: Mean \pm SD levels of ferritin, copper, and zinc according to cancer location $(\mathrm{mg} / \mathrm{dl})$

\begin{tabular}{lccc}
\hline Cancer location $(n)$ & Ferritin & Copper & Zinc \\
\hline Lower lip (11) & $167.4 \pm 136.691$ & $359.6 \pm 304.203$ & $148.5 \pm 77.568$ \\
Upper lip (3) & $84 \pm 75.498$ & $202 \pm 116.258$ & $112 \pm 13.528$ \\
Buccal mucosa (3) & $239.3 \pm 174.775$ & $139.3 \pm 6.658$ & $72 \pm 32.357$ \\
Anterior tongue (17) & $437.8 \pm 350.821$ & $192.2 \pm 94.077$ & $100.2 \pm 55.459$ \\
Mandible (12) & $235.3 \pm 118.908$ & $155.2 \pm 80.005$ & $104.9 \pm 26.800$ \\
Maxilla (3) & $141 \pm 113.635$ & $182.3 \pm 57.501$ & $120.3 \pm 47.857$ \\
Hard palate (2) & $512 \pm 299.813$ & $162 \pm 48.083$ & $105 \pm 48.083$ \\
Retromolar & 421 & 175 & 203 \\
trigone (1) & & & \\
Major salivary & $140 \pm 147.558$ & $181 \pm 64.720$ & $113.5 \pm 19.003$ \\
glands (parotid) (6) & & & \\
Alveolar ridge (1) & 217 & 136 & 117 \\
Floor of mouth (1) & 37 & 208 & 90 \\
\hline
\end{tabular}

In this way, free radicals have a role in development and prognosis of carcinogenesis and causing various cancers. Consequently, increase of serum copper level due to increase of oxidation processes may promote suitable grounds in individuals to develop oral cancer. There is a relationship between increase of serum copper level in patients suffering 
from oral cancers and that of activity of ceruloplasmin (globulin containing copper) with major oxidase activity ${ }^{[23]}$ in the serum of patients suffering from cancer.

Zinc is one of the rare elements whose serum level changes are effective in oxidation and regeneration processes as well as development of carcinogenesis. ${ }^{[17]}$ In this study, the value of serum zinc in individuals with oral cancer was apparently higher than in the control group. Changes have been observed in the serum levels of zinc in different tumor types. For example, the serum level of zinc in cancers of bladder, ${ }^{[16]}$ prostate ${ }^{[24]}$ stomach, ${ }^{[25]}$ and gall bladder has been found to be decreased, ${ }^{[26]}$ and in thyroid cancer, it has been found to be increased. ${ }^{[27]} \mathrm{Zinc}$ is one of the antioxidants in food on which the activities of enzymes of the antioxidant system of the body, such as superoxide dismutase, depend. ${ }^{[28]}$ Moreover, zinc may directly prevent DNA damage and eventually gene mutation, and in this way, the element decreases the risk of cancer accordingly. ${ }^{[29]}$

Concerning the fact that oral cancerous and precancerous lesions contain inflammatory processes, it seems that long-term inflammation, associated with the above-mentioned lesions, may irritate oxidative stress. Not only does zinc participate in the transcription process as a cofactor, but also it has a role playing an active part in the enzymatic antioxidant system, including carbonic anhydrase, superoxide dismutase, and leucine aminopeptidase. All the above factors take part in homeostasis of body against the tumor progression. ${ }^{[15,30]}$

Contrary to the results of the present study, Ray et al., indicated that serum value of zinc in patients with leukoplakia had clearly decreased. ${ }^{[31]}$ This finding may be related to the different nature of lesions. Moreover, values of zinc in patients with cancer were close to the normal range, while the individuals of control group showed lower values, which probably reveals nutritional deficiencies in Iranian population as shown in several studies. ${ }^{[32,33]}$

Unlike our results, Prasad et al., found zinc deficiency and dysfunction of cell-mediated immunity in a number of patients with head and neck cancers. ${ }^{[34]}$ Doerr et al., also reported that zinc inadequacy in patients with head and neck cancers has been associated with a few medical complications. ${ }^{[35]}$ Increased level of zinc in patients suffering from oral cancer may be related to their dietary habits.

Major mechanisms through which zinc may affect oral cancer are still the topic of discussion. Role of zinc in the synthesis of nucleic acid, its effects in producing metallothioneins, grabbing free radicals, and its importance in the activity of cytotoxic T cells all are significant, and inadequacy of zinc may lead to occurrence or aggravation of malignant oral lesions. Meanwhile, animal studies revealed that zinc may aggravate tumor prognosis ${ }^{[9]}$ Moreover, primary studies on human beings indicate the role of zinc and other micronutrients in inducing treatment effects in patients with precancerous and cancerous lesions, ${ }^{[1]}$ but more studies are required in this regard to elucidate the exact role of zinc in malignant lesions.

In this study, we measured the serum level of ferritin instead of serum iron to minimize the effect of daily diet on our results.

Results of this study showed that the value of serum ferritin in patients with oral cancer was apparently higher than that of healthy individuals. In cancers of liver, stomach, and colon, the serum level of ferritin is noticeably found to be increased compared to that of normal persons ${ }^{\left[{ }^{[6]}\right.}$ However, the serum level of ferritin in patients with bladder cancer showed a meaningful decrease ${ }^{[16]}$ High values of serum ferritin may occur in reaction to infection, inflammation, and chronic diseases. ${ }^{[37]}$ Ferritin levels may be increased in spite of ferritin deficiency or inadequacy. ${ }^{[38]}$ Increased level of ferritin has been reported in patients with oral disease, ${ }^{[39]}$ breast cancer, ${ }^{[00]}$ Hodgkin's disease, and surgery in some studies. ${ }^{[11,42]}$ Biochemical functions of ferritin justify the essential role of iron in carcinogenesis. ${ }^{[4]}$ Furthermore, review of literature showed that there are different concepts about the role of iron in carcinogenesis. Results of previous meta-analyses have not confirmed definite relationship between iron changes and cancer risk. However, in some studies, such relations have been proved. ${ }^{[42,43]}$

Ferritin is a part of the enzyme system which catalyzes electron transfer and respiration reactions, and has a pivotal role in cellular viability. ${ }^{[4]}$ According to the results of Hossain et al. study, serum ferritin in patients with oral squamous cell carcinoma (OSCC), compared to healthy individuals, was apparently decreased. ${ }^{[45]}$ Increase in serum ferritin may create free radicals and produce carcinogenesis effects. ${ }^{[46]}$

Limited studies have been conducted on the relationship between ferritin and the risk of oral cancer. According to three studies, it has been found that upon decrease of ferritin, certain changes may take place leading to development of oral cancer. ${ }^{[47-49]}$ On the other hand, no relationship was established between precancerous oral lesions and decrease of ferritin among Indian women. ${ }^{[50]}$

Khanna reported significantly decreased level of ferritin among patients with precancerous and cancerous lesions by means of calorimetric method, which is inconsistent with our study result. ${ }^{[51]}$

On the contrary, Richie et al., found a relationship between increased values of ferritin and total iron binding capacity with increased risk of oral cancer. ${ }^{[52]}$

Mahdavi et al., studied the levels of serum copper, zinc, iron, and ferritin in hyperlipidemic and healthy individuals, in which the levels of serum lipids and ferritin were measured using enzymatic method, the levels of serum copper and zinc were measured using atomic absorption spectrophotometric method, and the values of ferritin were measured using ELISA method. The above methods are inconsistent with the methods used in our research to some extent. ${ }^{[33]}$ 
The results of this study must be interpreted considering its certain limitations. First of all, levels of micronutrients in serum are affected by daily dietary patterns. Thus, in order to prove a definite role of the micronutrients for early diagnosis and improvement of prognosis, cohort complementary researches should be conducted.

Meanwhile, patients' biomarkers were measured after diagnosis of cancer and it was possible that their changes occurred due to alterations in recent dietary patterns.

Moreover, it is likely that development of oral cancer would change the balance of iron metabolism and affect serum ferritin accordingly. ${ }^{[52]}$

\section{Conclusions}

Serum levels of ferritin, copper, and zinc in patients with oral cancerous lesions are significantly higher than those of healthy people.

\section{Acknowledgments}

This article was based on an undergraduate thesis of Dental School, Shahid Beheshti University of Medical Sciences, which was successfully accomplished by Reihaneh Akkafan under the supervision of Dr. Maryam Baharvand and Dr. Soheila Manifar in the academic year 2012-2013.

This research was funded by Deputy of Research, Dental School, Shahid Beheshti University of Medical Sciences.

The authors are greatly thankful to the staff members and patients of Cancer Institute of Tehran University of Medical Sciences and Aftab Pathobiology Laboratory for their close cooperation and technical aids.

\section{REFERENCES}

1. Krishnaswamy K, Prasad MP, Krishna TP, Annapurna VV, Reddy GA. A case study of nutrient intervention of oral precancerous lesions in India. Eur J Cancer B Oral Oncol 1995;31:41-8.

2. Itagappa M, Rao SB. Cancer in south Karnataka and its paradoxical relation to diabetes mellitus. Indian J Clin Biochem 2004;19:6-9.

3. Paul RR, Chatterjee J, Das AK, Cervera ML, de la Guardia M, Chaudhuri K. Altered elemental profile as indicator of homeostatic imbalance in pathogenesis of oral submucous fibrosis. Biol Trace Elem Res 2002;87:45-56.

4. Fukuda H, Ebara M, Yamada H, Arimoto M, Okabe S, Obu M, et al. Trace elements and cancer. JMAJ 2004;47:391-395.

5. Pillai KG, Burde KN. Increased copper level in oral mucosal tissue of patients with submucous fibrosis who chew areca nut products. West Indian Med J 2005;54:270-1.

6. Raina C, Raizada RM, Chaturvedi VN, Harinath BC, Puttewar MP, Kennedy AK. Clinical profile and serum beta-carotene levels in oral submucous fibrosis. Indian J Otolaryngol Head Neck Surg 2005;57:191-5.

7. Prasad MP, Krishna TP, Pasricha S, Krishnaswamy K, Quereshi MA.
Esophageal cancer and diet--a case-control study. Nutr Cancer 1992;18:85-93.

8. Beguin Y, Bury J, Delbrouck JM, Fillet G, Robaye G, Roelandts I, et al. Serum zinc and copper as prognostic factors in acute nonlymphocytic leukemia. Hematol Blood Transfus 1987;30:380-4.

9. Prasad AS. Zinc: An overview. Nutrition 1995;11;93-9.

10. Knight JA. Free radicals: Their history and current status in aging and disease. Ann Clin Lab Sci 1998;28:331-46.

11. Toyokuni S. Reactive oxygen species-induced molecular damage and its application in pathology. Pathol Int 1999;49:91-102.

12. Salganik RI, Solovyova NA, Dikalov SI, Grishaeva ON, Semenova LA, Popovsky AV. Inherited enhancement of hydroxyl radical generation and lipid peroxidation in the strain rats results in DNA rearrangements, degenerative diseases, and premature aging. Biochem Biophys Res Commun 1994;199:726-33.

13. Yelinova V, Glazachev Y, Khramtsov V, Kudryashova L, Rykova V, Salganik R. Studies of human and rat blood under oxidative stress: Changes in plasma thiol level, antioxidant enzyme activity, protein carbonyl content, and fluidity of erythrocyte membrane. Biochem Biophys Res Commun 1996;221:300-3.

14. Trush MA, Kensler TW. An overview of the relationship between oxidative stress and chemical carcinogenesis. Free Radic Biol Med 1991;10:201-9.

15. Khanna S, Karjodkar FR. Circulating immune complexes and trace elements (Copper, Iron and Selenium) as markers in oral precancer and cancer: A randomised, controlled clinical trial. Head Face Med 2006;2:33.

16. Mazdak H, Yazdkhasty F, Mirkhesht N, Shafieyan M, Behzad E. Serum Iron, Copper, Zinc levels in bladder cancer patients in comparison with healthy individuals. Pejouhesh 2010;34:56-60.

17. Huang YL, Sheu JY, Lin TH. Association between oxidative stress and changes of trace elements in patients with breast cancer. Clin Biochem 1999;32:131-6.

18. Hronek M, Zadak Z, Solichova D, Jandik P, Melichar B. The association between specific nutritional antioxidants and manifestation of colorectal cancer. Nutrition 2000;16:189-91.

19. McMillan DC, Sattar N, Talwar D, O'Reilly DS, McArdle CS. Changes in micronutrient concentrations following anti-inflammatory treatment in patients with gastrointestinal cancer. Nutrition 2000; $16: 425-8$.

20. Mross K. Anti-angiogenesis therapy: Concepts and importance of dosing schedules in clinical trials. Drug Resist Update 2000;3:223-35.

21. Valko M, Rhodes CJ, Moncol J, Izakovic M, Mazur M. Free radicals, metals and antioxidants in oxidative stressinduced cancer. Chem Biol Interact 2006;160:1-40.

22. Theophanides T, Anastassopoulou J. Copper and carcinogenesis. Crit Rev Oncol Hematol 2002;42:57-64.

23. Jaydeep A, Raveendran Pillai K, Kannan S, Nalinakumari KR, Mathew B, Krishnan Nair M, et al. Serum levels of copper, zinc, iron and ceruloplasumin in oral leukoplakia and squamous cell carcinoma. J Exp Clin Cancer Res 1997;16:295-300.

24. Carvalho AL, Sanz L, Barettino D, Romero A, Calvete JJ, Romão MJ. Crystal structure of a prostate kallikrein isolated from stallion seminal plasma: A homologue of human PSA. J Mol Biol 2002;322:325-37.

25. Li Y, Xue Q, Chen L, Chen H, Chai C, Shi B, et al. Research 
on relationships of gastric cancer with serum trace elements, Helicobacter pylori and COX-2 in gastric tissue. Sheng Wu Yi Xue Gong Cheng Xue Za Zhi 2004;21:107-10.

26. Kumar SV, Kumar AT, Sureshwer SP, Chandra PM, Ravindra NM. Micronutrients, antioxidants, and carcinoma of the gallbladder. J Surg Oncol 2003;84:31-5.

27. Kucharzewski M, Braziewicz J, Majewska U, Gózdz S. Copper, zinc, and selenium in whole blood and thyroid tissue of people with various thyroid diseases. Biol Trac Elem Res 2003;93:9-18.

28. Marklund SL, Westman NG, Lundgren E, Roos G. Copper- and zinc-containing superoxide dismutase, manganese-containing superoxide dismutase, catalase, and glutathione peroxidase in normal and neoplastic human cell lines and normal human tissues. Cancer Res 1982;42:1955-61.

29. Anastassopoulou J, Theophanides T. Magnesium-DNA interactions and the possible relation of magnesium to carcinogenesis. Irradiation and free radicals. Crit Rev Oncol Hematol 2002;42:79-91.

30. Miceli MV, Tate DJ Jr, Alcock NW, Newsome DA. Zinc deficiency and oxidative stress in the retina of pigmented rats. Invest Ophthalmol Vis Sci 1999;40:1238-44.

31. Ray JG, Ghosh R, Mallick D, Swain N, Gandhi P, Ram SS, et al. Correlation of trace elemental profiles in blood samples of Indian patients with leukoplakia and oral submucous fibrosis. Biol Trace Elem Res 2011;144:295-305.

32. Prasad AS. Impact of the discovery of human zinc deficiency on health. J Am Coll Nutr 2009;28:257-65.

33. Prasad AS. Zinc deficiency. BMJ 2003;326:409-10.

34. Prasad AS, Beck FW, Doerr TD, Shamsa FH, Penny HS, Marks SC, et al. Nutritional and zinc status of head and neck cancer patients: An interpretive review. J Am Coll Nutr 1998;17:409-18.

35. Doerr TD, Marks SC, Shamsa FH, Mathog RH, Prasad AS. Effects of zinc and nutritional status on clinical outcomes in head and neck cancer. Nutrition 1998;14:489-95.

36. Olinski R, Gackowski D, Rozalski R, Foksinski M, Bialkowski K. Oxidative DNA damage in cancer patients: A cause or a consequence of the disease development? Mutat Res 2003;531:177-90.

37. Torti SV, Torti FM. Iron and ferritin in inflammation and cancer. Adv Inorg Biochem 1994;10:119-37.

38. Weiss G, Goodnough LT. Anemia of chronic disease. N Engl J Med 2005;352:1011-23.

39. Inal E, Laçin M, Asal K, Ceylan A, Köybaşioğlu A, Ileri F, et al. The significance of ferritin, lipid-associated sialic acid, CEA, squamous cell carcinoma (SCC) antigen, and CYFRA 21-1 levels in SCC of the head and neck. Kulak Burun Bogaz Ihtis Derg 2004;12:23-30.

40. Ulbrich EJ, Lebrecht A, Schneider I, Ludwig E, Koelbl H, Hefler LA Serum parameters of iron metabolism in patients with breast cancer. Anticancer Res 2003;23:5107-9.

41. Toyokuni S. Iron-induced carcinogenesis: The role of Redox regulution. Free Radic Biol Med 1996;20:553-66.

42. Knekt P, Reunanen A, Takkunen H, Aromaa A, Heliovaara M, Hakulinen T. Body iron stores and risk of cancer. Int J Cancer 1994;56:379-82.

43. Merk K, Mattsson B, Mattsson A, Holm G, Gullbring B, Björkholm M. The incidence of cancer among blood donors. Int J Epidemiol 1990;19:505-9.

44. Neilands JB. Evolution of biological iron binding center. Struct Bonding 1972;11:145-70.

45. Hossain S, Molla MR, Akhter M. Serum iron concentration and total iron binding capacity in patients of oral squamous cell carcinoma. Bangladesh J Pharmacol 2007;2:49-54.

46. Boldt DH. New perspectives on iron: An introduction. Am J Med Sci 1999;318:207-12.

47. Petridou E, Zavras AI, Lefatzis D, Dessypris N, Laskaris G, Dokianakis $\mathrm{G}$, et al. The role of diet and specific micronutrients in the etiology of oral carcinoma. Cancer 2002;94:2981-8.

48. Negri E, Franceschi S, Bosetti C, Levi F, Conti E, Parpinel M, et al. Selected micronutrients and oral and pharyngeal cancer. Int J Cancer 2000;86:122-7.

49. Rogers MA, Thomas DB, Davis S, Vaughan TL, Nevissi AE. A case-control study of element levels and cancer of the upper aerodigestive tract. Cancer Epidemiol Biomarkers Prev 1993;2:305-12.

50. Gupta PC, Hebert JR, Bhonsle RB, Murti PR, Mehta H, Mehta FS. Influence of dietary factors on oral precancerous lesions in a population-based case-control study in Kerala, India. Cancer 1999;85:1885-93.

51. Khanna S. Immunological and biochemical markers in oral carcinogenesis: The public health perspective. Int J Environ Res Public Health 2008;5:418-22.

52. Richie JP Jr, Kleinman W, Marina P, Abraham P, Wynder EL, Muscat JE. Blood iron, glutathione, and micronutrient levels and the risk of oral cancer. Nutr Cancer 2008;60:474-82.

53. Mahdavi R, Rasekhi H, Ostadrahimi A, Asadi Y, Vahed Jabbari M. Nutritional and Biochemical Status Of Copper, Zinc, $\mathrm{Zn} / \mathrm{Cu}$ Ratio, Iron and Iron Stores, in Hyperlipidemic and Healthy Men. Indian J Endocrinol Metab 2009;10:505-10. 